\title{
THE CARDIAC OUTPUT AT REST IN LAENNEC'S CIRRHOSIS ${ }^{1}$
}

\author{
BY HENRY J. KOWALSKI ${ }^{2}$ AND WALTER H. ABELMANN \\ (From the Thorndike Memorial Laboratory, Second and Fourth Medical Services [Harvard], \\ and the Department of Medicine, Harvard Medical School, Boston, Mass.)
}

(Submitted for publication April 29, 1953; accepted June 12, 1953)

\section{INTRODUCTION}

Patients with Laennec's cirrhosis and those with occidental beri-beri frequently have the common background of consumption of alcoholic beverages and inadequate diet of long duration. A short circulation time which may be found in occidental beri-beri (1) and in Laennec's cirrhosis $(2,3)$ suggests an elevated cardiac output. In the case of beri-beri, this has been verified $(4,5,6,7)$, but, to our knowledge, direct measurements of systemic blood flow have not been reported in chronic liver disease. Increased flow of blood to the periphery in patients with Laennec's cirrhosis is suggested by the frequent occurrence of warm extremities, cutaneous vascular spiders, wide pulse pressure, and capillary pulsations in the nail beds.

The present study reports measurements of the resting cardiac output, blood pressure, and peripheral resistance in patients with chronic alcoholism and disease of the liver.

\section{MATERIALS AND METHODS}

\section{Selection of patients}

Twenty-two hospitalized patients 8 with clinical and/or laboratory evidence of chronic parenchymal disease of the liver were studied. Only patients without clinical evidence of co-existing heart disease and without evidence of acute gastro-intestinal bleeding were included. All subjects gave a history of excessive intake of alcoholic beverages and an irregular and inadequate diet of longstanding.

Of the 22 patients studied, three had "fatty liver," 11 had Laennec's cirrhosis without fluid retention, and eight had Laennec's cirrhosis with either ascites or peripheral edema or both. Of the 19 patients with Laennec's

1 Presented in part at the Eastern Section Meeting of the American Federation for Clinical Research, December 5, 1952, New York, N. Y.

2 Postdoctoral Research Fellow, Life Insurance Medical Research Fund.

8 We appreciate the courtesy of Dr. Charles S. Davidson and his associates, and of the various medical services of the Boston City Hospital for making their patients available for study. cirrhosis, all save one (No. 17) had enlargement of the liver, and all but two (Nos. 11 and 18) had cutaneous vascular spiders. All 22 patients had abnormally high Bromsulfalein retention.

A diagnosis of "fatty liver" was made clinically when there was enlargement of the liver and laboratory evidence of hepatic dysfunction without the following : icterus, cutaneous vascular spiders, ascites, edema, splenomegaly, or prominent abdominal veins.

\section{PROCEDURES}

Each patient was studied early in the morning without any premedication, fasting and recumbent. An indwelling needle was inserted into the left brachial artery and a similar needle was placed into a right antecubital vein. The patient then was allowed to rest for at least twenty minutes.

\section{Cardiac output}

The cardiac output was determined by the dye-injection method as described by Hamilton and his co-workers (8). Five mg. of a 0.5 per cent solution of Evans blue dye were injected rapidly through the venous needle from a tuberculin syringe previously calibrated by weighing. The dead space of the indwelling needle was known and accounted for in determining the amount of dye injected. Samples of arterial blood were collected from the arterial needle through a short length of polyethylene tubing into heparinized tubes mounted along the rim of a circular lucite disc equipped with funnels arranged so that spillage between tubes was minimized. The disc was rotated about a centrally placed vertical shaft by a variable-speed electric motor. The usual collection time for each tube was two and one-half seconds. Samples of arterial blood were centrifuged for 20 minutes at $3,000 \mathrm{rpm}$. and the concentration of dye in undiluted plasma was determined in micro-cells of 0.5 cc. capacity at a wave length of $625 \mathrm{~m} \mu$. using a Beckmann Model DU spectrophotometer. In most patients duplicate estimations were made.

The cardiac index was calculated from the cardiac output and the body surface area using the height and weight at time of study irrespective of the presence or absence of edema. In subjects with marked obesity and perhaps in those with abnormal fluid retention, the body surface area calculated according to Du Bois and Du Bois (9) might. distort the predicted value for cardiac index $(10,11)$. The cardiac output also was expressed in terms of oxygen consumption as a ratio by the formula:

Cardiac output L./min. $\times 100$

Oxygen consumption cc./min. 
TABLE I

Cardiac index-"normal" values"

\begin{tabular}{|c|c|c|c|c|}
\hline & & & Mean & $\begin{array}{c}\text { Standard deviation } \\
\text { of sample }\end{array}$ \\
\hline Authors & $\begin{array}{l}\text { No. } \\
\text { subjects }\end{array}$ & Method & Cardiac index & $\frac{\text { Cardiac output L. } / \mathrm{min} . \times 100}{\text { Oxygen consumption cc. } / \mathrm{min} .}$ \\
\hline $\begin{array}{l}\text { Cournand et al. } \\
\text { (J. Clin. Invest., } \\
1945,24,106 .)\end{array}$ & 30 & Fick & $3.31 \pm 0.54$ & $2.32 \pm 0.32$ \\
\hline $\begin{array}{l}\text { Stead et al. } \\
\text { (J. Clin. Invest., } \\
1945,24,326 .)\end{array}$ & 18 & Fick & $3.27 \pm 0.57$ & $2.52 \pm 0.39$ \\
\hline $\begin{array}{l}\text { Ebert et al. } \\
\text { (J. Clin. Invest., } \\
1949,28,1134 .)\end{array}$ & 12 & Fick & $3.59 \pm 0.72$ & $2.64 \pm 0.34$ \\
\hline $\begin{array}{l}\text { Chapman et al. } \\
\text { (J. Clin. Invest.; } \\
\text { 1950, 29, 651.) }\end{array}$ & 7 & Fick & $3.27 \pm 0.62$ & $2.67 \pm 0.43$ \\
\hline $\begin{array}{l}\text { Dexter et al. } \\
\text { J. Applied Physiol., } \\
\text { 1951, 3, 439.) }\end{array}$ & 7 & Fick & $3.79 \pm 0.83$ & $2.77 \pm 0.37$ \\
\hline $\begin{array}{l}\text { Doyle et al. } \\
\text { (J. Clin. Invest., } \\
1951,30,345 .)\end{array}$ & 10 & $\begin{array}{l}\text { Fick } \\
\text { Dye }\end{array}$ & $\begin{array}{l}3.52 \pm 0.79 \\
2.85 \pm 0.40\end{array}$ & $\begin{array}{l}2.41 \pm 0.35 \\
1.97 \pm 0.87\end{array}$ \\
\hline $\begin{array}{l}\text { Freis et al. } \\
\text { (J. Clin. Invest., } \\
\text { 1952, 31, 131.) }\end{array}$ & 8 & Dye & $4.19 \pm 0.81$ & \\
\hline Present Authors & 12 & Dye & $3.76 \pm 0.65$ & \\
\hline
\end{tabular}

* Calculated by us from data in sources listed. Subjects with "anxiety" excluded as in individual reports. Two or more observations on the same subject were averaged, and the mean was used in these calculations.

Table I indicates values of cardiac index as reported by others and as determined in this laboratory using the dyeinjection method in subjects who were considered essentially normal. Also shown are values for the ratio of cardiac output to oxygen consumption.

\section{Oxygen consumption}

Oxygen consumption was determined over a six-minute period by means of a closed circuit water spirometer filled with oxygen, after the cardiac output studies were completed.

\section{Arterial pressure}

Phasic and mean arterial pressures were measured directly by means of an electromanometer of the condensermicrophone type and recorded on a direct writing oscillograph.

\section{Peripheral resistance}

The formula used was (12):

Resistance $=\frac{\text { Mean arterial pressure } \mathrm{mm} . \mathrm{Hg} \times 1332}{\text { Cardiac output } \mathrm{cc} . / \mathrm{sec} .}$

4 Made by Sanborn Company, Cambridge, Massachusetts.

\section{Venous pressure}

Venous pressure was estimated by means of a saline manometer attached to the indwelling needle located in the antecubital vein, and referred to a zero point $5 \mathrm{~cm}$. below the angle of Louis.

\section{RESULTS}

The data are found in Table II.

\section{Cardiac output (Figure 1)}

The mean cardiac index of patients with disease of the liver was $4.26 \mathrm{~L}$. per min. per $\mathrm{M}^{2}$, and the standard deviation of the sample was $\pm 2.73 \mathrm{~L}$. per min. per $\mathbf{M}^{2}$. Values below the normal range were not seen, and in seven patients they were above the normal range.

As indicated in Figure 1, elevations of output were noted in one of the three patients with "fatty liver" as well as in patients with cirrhosis, irrespective of the presence or absence of abnormal fluid retention or of jaundice. 


\begin{tabular}{|c|c|c|c|c|c|c|c|c|c|c|c|c|c|c|c|c|}
\hline 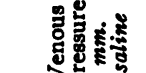 & & & ర్లి & \& & & \& & $\ddot{\circ}$ & \&్ర & ৪ & & & 오 & & & & \\
\hline $\bar{\square}$ & & $\underset{7}{\sharp}$ & ‡̛̣ & 욲 & & ợ & జึ & F! & 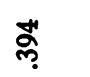 & চ్లై & $\stackrel{\infty}{\dddot{f}}$ & ษั & ষ্ণ & & ஜ్ల్ & $\exists$ \\
\hline 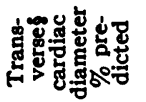 & & 8. & & \& & & $\stackrel{\infty}{\circ}$ & $\exists$ & ஃ & 요 & $\stackrel{\Xi}{\exists}$ & 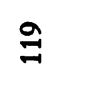 & $\stackrel{\dddot{Z}}{\exists}$ & ฮั & 苍 & $\stackrel{m}{=}$ & \\
\hline 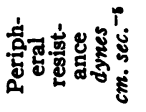 & & สิ & ర్రి & : & & 苟 & 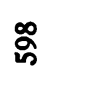 & ฉั & $\stackrel{\infty}{\infty}$ & 㱏 & ర్ః & $\stackrel{9}{\Xi}$ & 尲 & $\overrightarrow{\bar{\sigma}}$ & 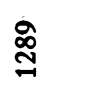 & ஜ \\
\hline \begin{tabular}{l|l}
$\dot{g}$ \\
$\mathbf{g}$
\end{tabular} & & $\infty$ & 훅 & $\cong$ & & $\ddot{\infty}$ & ஓ & $\mathbb{N}$ & ః & $\infty$ & $\infty$ & ஃ & $\hat{a}$ & $\infty$ & ฉి & ঙ્తి \\
\hline 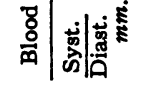 & & $\left.\Xi ゙\right|^{\infty}$ & 요요 & $\left.\stackrel{n}{n}\right|^{\infty}$ & & $\stackrel{m}{=} 18$ & 이요 & gan & $\stackrel{0}{0}$ & 례요 & ఏ야 & ఫ్రిळ & 矛|ळ & $\stackrel{\infty}{=} \mid R$ & શิ|స & 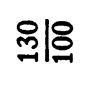 \\
\hline 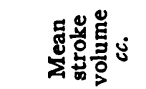 & & $\stackrel{Ð}{\dddot{\Xi}}$ & 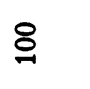 & 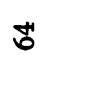 & & $\overrightarrow{0}$ & $\stackrel{\mathscr{3}}{=}$ & $\stackrel{2}{\underset{7}{*}}$ & $\vec{a}$ & 홍 & $\widehat{\infty}$ & ఫే & $\hat{\infty}$ & $f$ & $\therefore$ & 오 \\
\hline 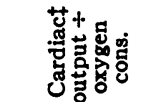 & & ָั & $\stackrel{m}{m}$ & $\stackrel{N}{N}$ & 兽 & min & $\stackrel{8}{\circ}$ & $\underset{m}{~}$ & $\underset{\dot{m}}{8}$ & $\stackrel{\sim}{\sim}$ & $\hat{i}$ & $\vec{i}$ & & & $\stackrel{N}{\sim}$ & $\stackrel{\overrightarrow{0}}{-i}$ \\
\hline ฐ్లँ & & $\begin{array}{l}\infty \\
\stackrel{\infty}{\infty}\end{array}$ & $\stackrel{\sim}{\infty}$ & $\hat{n}$ & 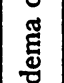 & $\stackrel{\infty}{0}$ & 吕 & $\bar{m}$ & $\stackrel{2}{+}$ & $\stackrel{\sim}{+}$ & $\underset{+}{4}$ & $\overrightarrow{\bar{m}}$ & 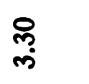 & $\underset{\dot{m}}{\stackrel{0}{0}}$ & $\underset{\text { กั }}{\tilde{m}}$ & $\stackrel{p}{i}$ \\
\hline 跑 & 导 & ㅎํ: & 음 & 早离 & 总 & 웅: & 옹 ్ㅗㅇ & 年 & $\stackrel{\infty}{\stackrel{\infty}{*}}$ & ชั & $\underset{+1}{4}$ & $\vec{a}$ & ঙ্লm & 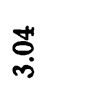 & 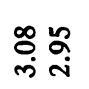 & م્م \\
\hline & & 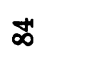 & $\bowtie$ & $\approx$ & . & ¿ & $\widehat{\infty}$ & 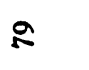 & $\infty$ & 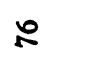 & $\infty$ & §్తి & ชิ & \& & $\approx$ & $\stackrel{\infty}{\circ}$ \\
\hline 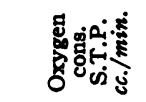 & & ฉ્సి & ณొ & ఏ્े & 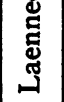 & $\overline{2}$ & ๙ิ & జే & $\stackrel{M}{d}$ & స్లు & $\stackrel{\infty}{\infty}$ & ๙ু & & & 虽 & 芦 \\
\hline ్ㅜㅂㅇㅇ & & $\dddot{7}$ & $\dddot{7}$ & बे & & ి్లి & $\stackrel{\infty}{\infty}$ & ని & ల్ & $\stackrel{\infty}{\infty}$ & $\mathscr{F}$ & f & "ే & $\$$ & $\stackrel{\infty}{+}$ & $\overline{7}$ \\
\hline 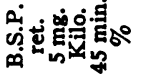 & & & $\tilde{m}$ & $\simeq$ & & ి్లి & Hే & $\hat{\sim}$ & $\mathscr{7}$ & & $\approx$ & $\stackrel{\infty}{\leftrightarrow}$ & $\approx$ & 命 & & นn \\
\hline 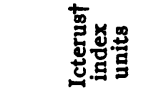 & & $\stackrel{\circ}{\mathrm{V}}$ & ণิ & $\frac{O}{\mathrm{v}}$ & & $\stackrel{\circ}{\mathrm{v}}$ & 유 & 을 & $\stackrel{8}{\wedge}$ & i & $\stackrel{O}{\mathrm{~V}}$ & 옹 & $\stackrel{\circ}{\mathrm{V}}$ & ণ্ণ & $\stackrel{\circ}{\mathrm{V}}$ & శ్ \\
\hline 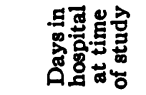 & & $r$ & $N$ & $\rightarrow$ & & $\approx$ & ส & $\mathscr{N}$ & 2 & 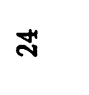 & ฮ్ & జి & $\Xi$ & $\mathcal{N}$ & -1 & $\vec{r}$ \\
\hline 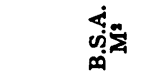 & & $\stackrel{\infty}{\longleftarrow}$ & 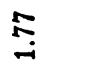 & $\stackrel{R}{\sim}$ & & $\stackrel{\widehat{\sigma}}{\circ}$ & $\stackrel{9}{-1}$ & ๙ั & $\stackrel{\infty}{\stackrel{+}{+}}$ & $\stackrel{0}{i}$ & $\stackrel{\infty}{-\infty}$ & $\stackrel{\Xi}{\circ}$ & $\stackrel{n}{0}$ & $\stackrel{+}{\rightarrow}$ & $\stackrel{\infty}{\rightarrow}$ & $\stackrel{1}{-1}$ \\
\hline ஜ & & $\Sigma$ & $\Sigma$ & $\Sigma$ & & ar & $\Sigma$ & 15 & 口 & $\Sigma$ & $\Sigma$ & $\Sigma$ & $\Sigma$ & $\Sigma$ & $\Sigma$ & $\Sigma$ \\
\hline 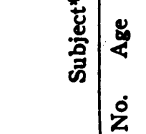 & & $\stackrel{2}{\not+}$ & $\begin{array}{l}\$ \\
N\end{array}$ & $\begin{array}{l}F \\
m\end{array}$ & & P & F & $\begin{array}{l}9 \\
0\end{array}$ & 岕 & $\begin{array}{l}\$ \\
\infty\end{array}$ & $\begin{array}{l}\text { o } \\
a\end{array}$ & $\begin{array}{l}3 \\
9\end{array}$ & $\begin{array}{l}\overrightarrow{\text { in }} \\
\Rightarrow\end{array}$ & $\begin{array}{l}\mathscr{P} \\
\simeq\end{array}$ & in & $\begin{array}{l}F \\
\nexists\end{array}$ \\
\hline
\end{tabular}




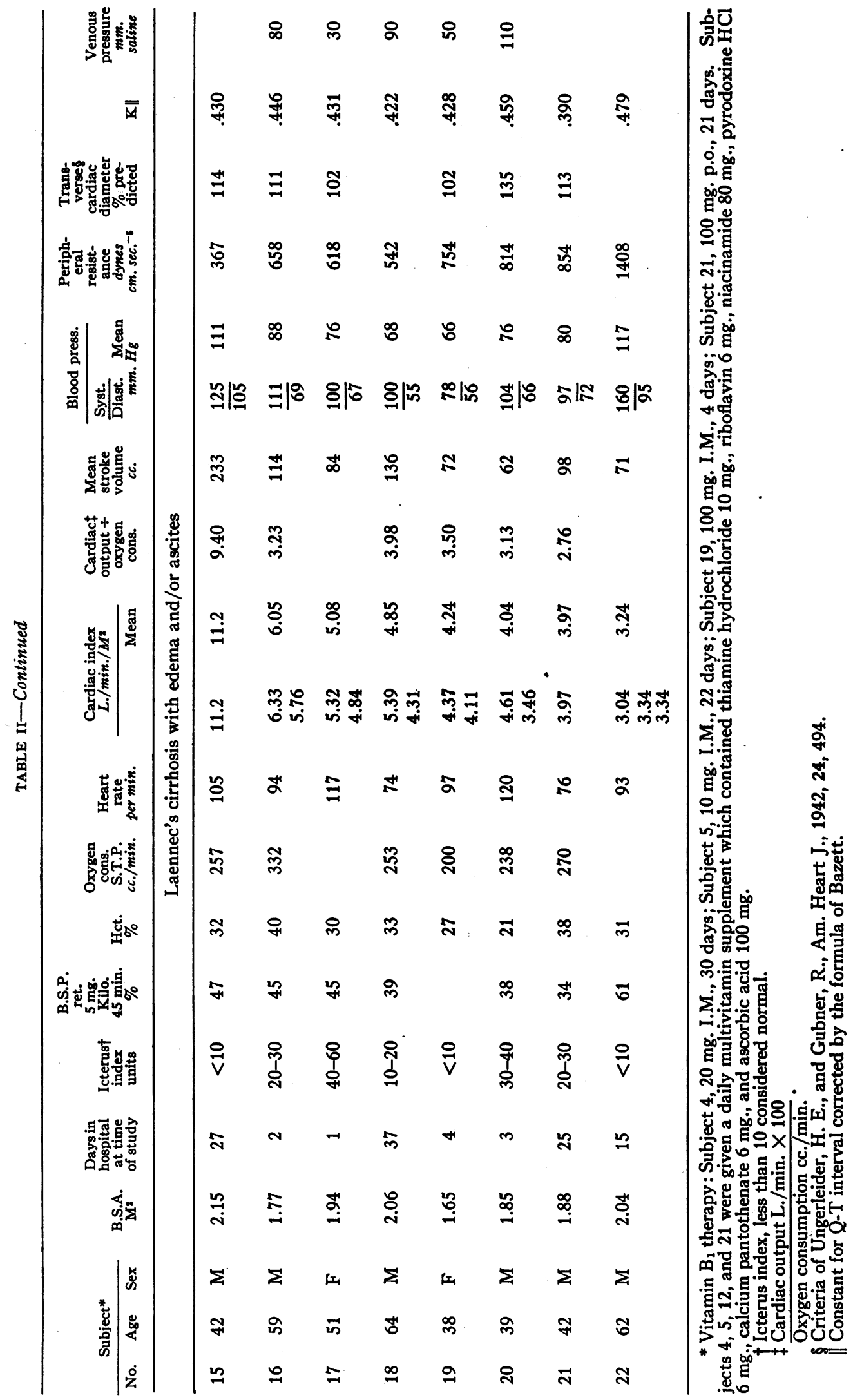




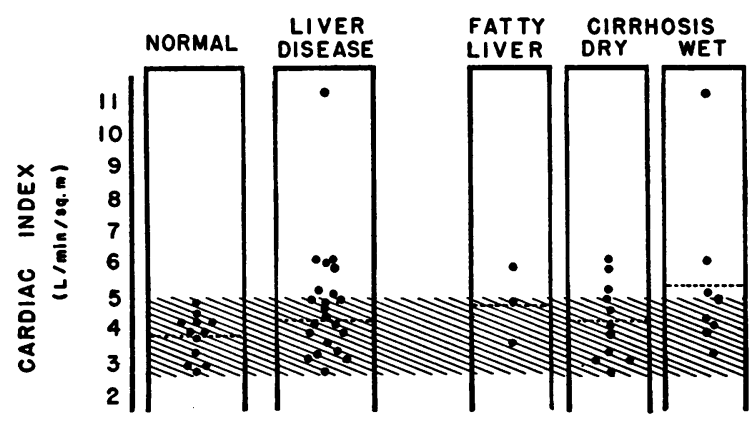

Fig. 1. Scatter of Cardiac Index

The second column represents all patients with liver disease. The third, fourth, and fifth are subdivisions of column two. The mean for each group is indicated by the dotted line. The shaded area represents the normal mean \pm two standard deviations of the sample.

Although one patient (No. 15) had a very high cardiac index, $11.2 \mathrm{~L}$. per min. per $\mathrm{M}^{2}$, this apparently did not unduly influence the mean of 4.76 since the median value for the series lay between 4.62 and $4.24 \mathrm{~L}$. per min. per $\mathrm{M}^{2}$. (This individual was restudied six weeks later at which time his cardiac index was $16.3 \mathrm{~L}$. per min. per $\mathrm{M}^{2}$ and his oxygen consumption was $263 \mathrm{cc}$. per min.)

The mean value of the ratio,

$$
\frac{\text { cardiac output L./min. } \times 100}{\text { oxygen consumption cc. } / \mathrm{min} \text {. }}
$$

in the patients with liver disease was 3.47 and ranged from 1.61 to 9.4. In contrast the mean values of this ratio in normal subjects (Table I) range from 1.97 to 2.77 . Elevated ratios were found in patients with cirrhosis with and without fluid retention and in patients with "fatty liver."

Figure 2 is a plot of cardiac index against the cardiac output-oxygen consumption ratio. Those patients with the highest value of cardiac index had the highest ratios, suggesting that where the cardiac output is elevated such elevations are not accompanied by parallel increases in oxygen consumption.

\section{Arterial pressure}

Values for mean arterial pressure ranged from 66 to $120 \mathrm{~mm}$. Hg. Patients with the higher pressures generally had normal outputs with one exception (No.15), whose mean pressure was $111 \mathrm{~mm}$. $\mathrm{Hg}$ at a time when his cardiac index was $11.2 \mathrm{~L}$. per min. per $\mathrm{M}^{2}$.

\section{Peripheral resistance}

Values ranged from 367 to 1965 dynes-cm.seconds $^{-5}$ with a mean of 955 , a value within accepted normal standards (13). Peripheral resistance was inversely related to cardiac output as seen in Figure 3. The mean resistance of the seven patients with high cardiac outputs was 596, a low value.

\section{Venous pressure}

Antecubital venous pressures where measured were within normal limits. Neck veins were not distended in recumbency in any patients.
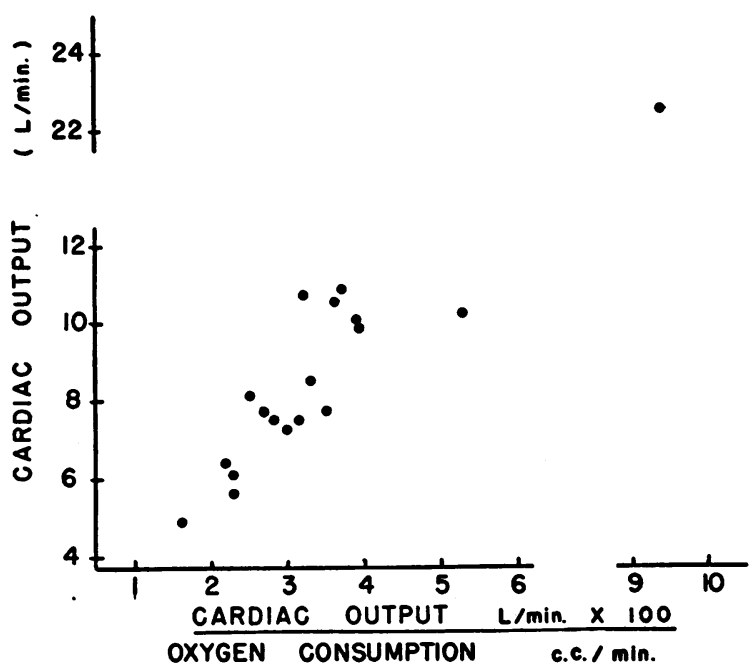

Fig. 2. Relation of Cardiac OUtput to Oxygen Consumption at Different Levels of Cardiac OUtput

\section{Heart rate and stroke volume (Figure 4)}

A slight elevation of resting heart rate was a feature of most patients with liver disease. Although the patients with the highest outputs tended to have faster rates, there was no consistent association between output and rate. Elevations of stroke volume as opposed to tachycardia were the immediate mechanism which produced the elevations in output.

\section{Heart size}

With the exception of two individuals (Nos. 17 and 22), all patients were examined by fluoroscopy. No chamber enlargement was noted. Unusually vigorous cardiac pulsations were conspicuous in 


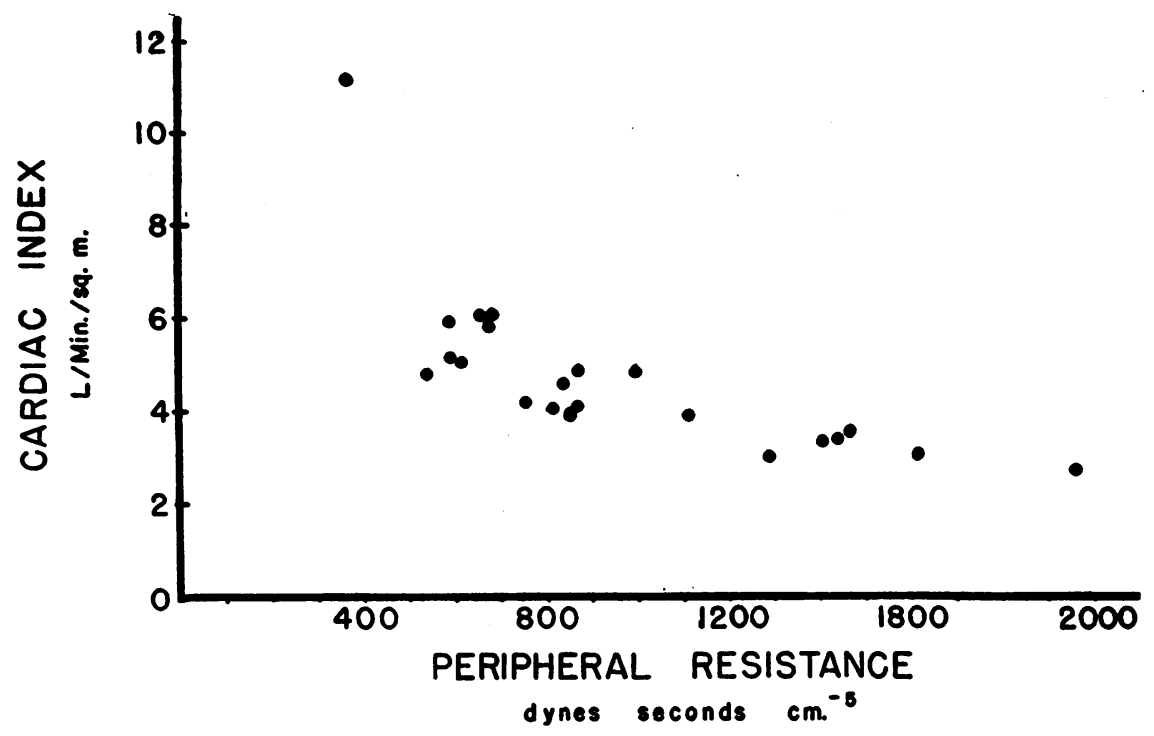

Fig. 3. Relation of Total Permpheral Vascular Resistance to Cardiac Index

some patients and frequently were associated with large stroke volumes.

The transverse diameter of the heart measured from teleoroentgenograms averaged 110 per cent of predicted values. (Normal range $=90$ per cent to 110 per cent.) The mean transverse diameter in the seven patients with elevated outputs averaged 105 per cent of predicted values. Heart size, then, was not abnormal.

\section{Electrocardiograms}

The Q-T interval was prolonged in eight patients using the criteria of Shipley and Hallaran

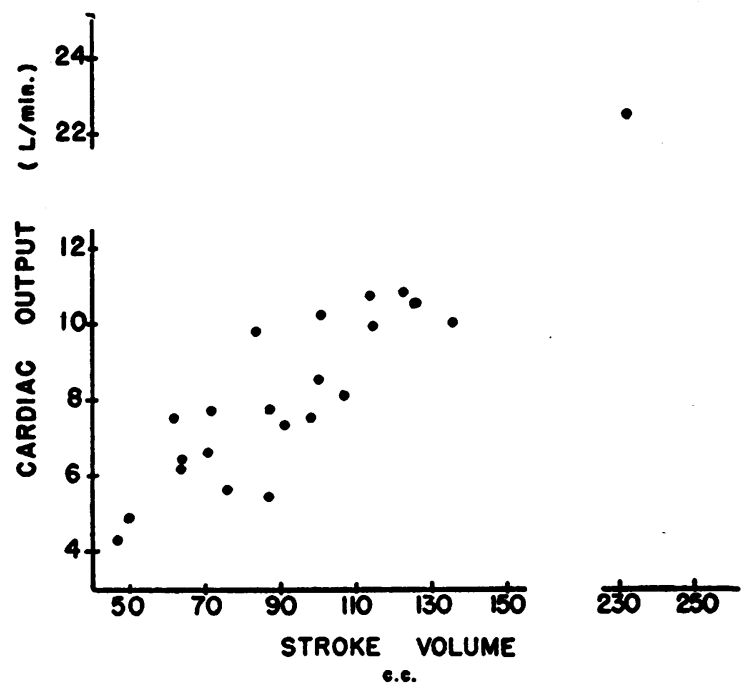

Fig. 4. Relation of Stroke Volume to Cardiac Output
(14). Four of the eight had a high cardiac output. All electrocardiograms otherwise were within normal limits.

\section{DISCUSSION}

The data indicate that the cardiac output determined at rest and in recumbency may be normal or distinctly elevated in patients with chronic alcoholism and parenchymal disease of the liver.

When the output is increased, it is out of proportion to the oxygen consumption or, by implication from the Fick formula (C.O.= oxygen consumption/arterio-venous oxygen difference), the arterio-venous oxygen difference must be decreased. The increase in blood flow is mainly accomplished by a larger output per beat. Since the arterial pressures are essentially normal, the increased blood flow is associated with decreased total vascular resistance. The hemodynamic picture in these subjects with elevated outputs resembles the high output state as seen in beri-beri heart disease $(4,5,6,7)$ and in the "shunt circulation" of arterio-venous fistulae $(15,16)$ or Paget's disease (17).

Several factors might be involved in producing the elevated outputs seen in one-third of the present series :

Anxiety, which may elevate the cardiac output $(13,18,19)$, does not appear responsible for the increase in blood flow since the subjects were relaxed, indifferent, and without overt resentment. 
Anemia, a frequent feature of parenchymal disease of the liver, is associated with an elevation of cardiac output when the hemoglobin falls to about $7 \mathrm{Gm}$. per $100 \mathrm{cc}$. or the hematocrit to about 20 per cent (20). Anemia of such degree was not seen in these patients, and since high values for cardiac output were seen in subjects with normal or near normal hematocrits, anemia does not adequately explain the elevated output.

All subjects gave a history of longstanding consumption of alcohol combined with a poor dietary intake. This background is similar to that of patients with occidental beri-beri as reported by Weiss and Wilkins (1) and by Blankenhorn (21). However, in our patients, clinical evidence of thiamine deficiency, such as neuritis, was absent, venous pressure was not elevated, cardiac enlargement was not evident, and heart failure was not seen. Four of the seven subjects with elevated outputs (Nos. 4, 5, 6, and 15) had been hospitalized 22 days or longer before study, and during this time they consumed nutritious diets under supervision. Two of these four patients (Nos. 42 and 5 ), in addition, were given supplementary thiamine chloride parenterally (Table II). In view of these facts, occidental beri-beri seems unlikely as an explanation of the elevated outputs seen in some patients.

Elevated concentrations of blood pyruvic and lactic acid have been noted in some patients with cirrhosis $(22,23,24)$. This raises the possibility of impaired utilization of thiamine even in the presence of adequate amounts of the vitamin.

The high output state noted in some patients may be related to a deficiency state other than beri-beri. However, Howarth (25) studied the resting cardiac output in 20 severely malnourished individuals with hunger edema, and without evidence of vitamin deficiencies. The outputs were normal or low. The nutritional heart disease described in association with liver disease in the South African Bantu (26) also appears associated with normal or low cardiac outputs at least at the stage of the disease observed.

The existence of arterio-venous communications in normal as well as in cirrhotic livers has been demonstrated by Herrick, by Prinzmetal and his co-workers, and by Dock $(27,28,29)$. The role of these communications in producing elevations of cardiac output would not seem great since estimates of hepatic blood flow and splanchnic arterio-venous oxygen difference $(30,31)$ suggest the former is decreased and the latter increased in subjects with cirrhosis.

The site of the increased blood flow thus would seem to lie in the periphery of the body, and we fall back on the concept suggested by Weiss and Wilkins (1) in explanation of the circulatory changes in beri-beri, namely that there exists generalized peripheral arteriolar dilatation, acting in effect like multiple arterio-venous shunts in parallel.

Shorr, Zweifach, Furchtgott, and Baez (32) have demonstrated that a vasodilator material, VDM, is produced by the liver under anaerobic conditions, and that it is inactivated by normal but not by anoxic liver tissue. Moreover, VDM was not inactivated under aerobic conditions by the livers of cirrhotic rats (33). It is thus conceivable that in human cirrhosis VDM is increased, or there is an imbalance in the VDM-VEM system in favor of VDM. This, then, could be a mechanism involved in the production of peripheral vaso-dilatation.

In the final analysis, we do not know whether the elevated outputs are related specifically to hepatic disease, or to a form of chronic malnutrition, or even whether they may represent the circulatory response of certain patients with chronic alcoholism to the laboratory situation.

The high incidence of prolongation of the $Q-T$ interval is of interest in relation to similar electrocardiographic findings observed in occidental beriberi (1), and in general deficiency states not related to thiamine deficiency (34). Prolongation of the $Q-T$ interval has been noted by other workers in cirrhosis $(35,36)$.

\section{SUM MARY}

Observations made in 22 patients with a history of alcoholism, and inadequate diet, and cirrhosis of the liver indicate that the resting cardiac output was elevated in one-third of the patients and was associated with a large stroke volume, normal blood pressure, and low peripheral vascular resistance. Where the cardiac output was high, it was elevated out of proportion to the oxygen consumption, indicating a decreased arterio-venous oxygen difference. 
It is suggested that dilatation of the peripheral vascular bed is responsible for the increased blood flow.

\section{ACKNOWLEDGMENTS}

We are grateful for the technical assistance of Miss Bernice E. Fingerman.

We express our gratitude to Dr. Laurence B. Ellis for his encouragement and advice throughout this investigation.

\section{REFERENCES}

1. Weiss, S., and Wilkins, R. W., The nature of the cardiovascular disturbances in nutritional deficiency states (beri-beri). Ann. Int. Med., 1937, 11, 104.

2. Dock, W., Present concepts regarding the mechanism of heart failure. Bull. St. Francis Sanatorium, 1951, 8 (no. 3), 1.

3. Abelmann, W. H., Unpublished observations, 1950 1951.

4. Porter, R. R., and Downs, R. S., Some physiological observations on the circulation during recovery from Vitamin $B_{1}$ deficiency. Ann. Int. Med., 1942, 17, 645.

5. Burwell, C. S., and Dexter, L., Beri-beri heart disease. Tr. A. Am. Physicians, 1947, 60, 59.

6. Campbell, J. A., Selverstone, L. A., and Donovan, D. L., Studies on the high output cardiac failure of occidental beriberi. J. Clin. Invest., 1951, 30, 632.

7. Lahey, W. J., Arst, D. B., Silver, M., Kleeman, C. R., and Kunkel, P., Physiologic observations on a case of beriberi heart disease, with a note on the acute effect of thiamine. Am. J. Med., 1953, 14, 248.

8. Hamilton, W. F., Riley, R. L., Attyah, A. M., Cournand, A., Fowell, D. M., Himmelstein, A., Noble, R. P., Remington, J. W., Richards, D. W., Jr., Wheeler, N. C., and Witham, A. C, Comparison of the Fick and dye injection methods of measuring the cardiac output in man. Am. J. Physiol., 1948, 153, 309.

9. DuBois, D., and DuBois, E. F., Clinical calorimetry. $\mathrm{X}$. A formula to estimate the approximate surface area if height and weight be known. Arch. Int. Med., 1916, 17, 863.

10. Tanner, J. M., Fallacy of per-weight and per-surface area standards, and their relation to spurious correlation. J. Applied Physiol., 1949, $2,1$.

11. Taylor, H. L., Brozek, J., and Keys, A., Basal cardiac function and body composition with special reference to obesity. J. Clin. Invest., 1952, 31, 976.

12. Cournand, A., Riley, R. L., Bradley, S. E., Breed, E. S., Noble, R. P., Lauson, H. D., Gregersen, M. I., and Richards, D. W., Jr., Studies of the circulation in clinical shock. Surgery, 1943, 13, 964.

13. Stead, E. A., Jr., Warren, J. V., Merrill, A. J., and Brannon, E. S., The cardiac output in male subjects as measured by the technique of right atrial catheterization. Normal values with observations on the effect of anxiety and tilting. J. Clin. Invest., 1945, 24, 326.

14. Shipley, R. A., and Hallaran, W. R., The four-lead electrocardiogram in two hundred normal men and women. Am. Heart J., 1936, 11, 325.

15. Ellis, L. B., and Weiss, S., The local and systemic effects of arterio-venous fistula on the circulation in man. Am. Heart J., 1930, 5, 635.

16. Warren, J. V., Nickerson, J. L., and Elkin, D. C., The cardiac output in patients with arteriovenous fistulas. J. Clin. Invest., 1951, 30, 210.

17. Edholm, O. G., Howarth, S., and McMichael, J., Heart failure and bone blood flow in osteitis deformans. Clin. Sc., 1945, 5, 249.

18. Grollman, A. P., Physiological variations in the cardiac output of man. IV. The effect of psychic disturbances on the cardiac output, pulse, blood pressure, and oxygen consumption of man. Am. J. Physiol., 1929, 89, 584.

19. Hickam, J. B., Cargill, W. H., and Golden, A., Cardiovascular reactions to emotional stimuli. Effect on the cardiac output, arteriovenous oxygen difference, arterial pressure, and peripheral resistance. J. Clin. Invest., 1948, 27, 290.

20. Brannon, E. S., Merrill, A. J., Warren, J. V., and Stead, E. A., Jr., The cardiac output in patients with chronic anemia as measured by the technique of right atrial catheterization. J. Clin. Invest., 1945, 24, 332.

21. Blankenhorn, M. A., The diagnosis of beriberi heart disease. Ann. Int. Med., 1945, 23, 398.

22. Weiss, S., and Ellis, L. B., Oxygen utilization and lactic acid production in the extremities during reșt and exercise in subjects with normal and in those with diseased cardiovascular systems. Arch. Int. Med., 1935, 55, 665.

23. Williams, R. H., and Bissell, G. W., Thiamine metabolism with particular reference to the role of the liver and kidneys. Arch. Int. Med., 1944, 73, 203.

24. Amatuzio, D. S., and Nesbitt, S., A study of pyruvic acid in the blood and spinal fluid of patients with liver disease with and without hepatic coma. J. Clin. Invest., 1950, 29, 1486.

25. Howarth, S., Cardiac output and the peripheral circulation in malnourished subjects. (Wuppertal, B.A.O.R., 1946) Proc. Physiol. Soc., 17-18 Dec. 1948, abstracted, J. Physiol., 1949, 109, 14P.

26. Gillanders, A. D., Nutritional heart disease. Brit. Heart J., 1951, 13, 177.

27. Herrick, F. C., An experimental study into the cause of the increased portal pressure in portal cirrhosis. J. Exper. Med., 1907, 9, 93.

28. Prinzmetal, M., Ornitz, E. M., Jr., Simkin, B., and Bergman, H. C., Arterio-venous anastomoses in liver, spleen, and lungs. Am. J. Physiol., 1948, 152, 48.

29. Dock, W., The rôle of increased hepatic arterial flow in portal hypertension of cirrhosis. Tr. A. Am. Physicians, 1942, 57, 302. 
30. Bradley, S. E., Ingelfinger, F. J., and Bradley, G. P., Hepatic circulation in cirrhosis of the liver. Circulation, 1952, 5, 419.

31. Myers, J. D., The hepatic blood flow in Laennec's cirrhosis with an estimate of the relative contributions from portal vein and hepatic artery. J. Clin. Invest., 1950, 29, 836.

32. Shorr, E., Zweifach, B. W., Furchtgott, R. F., and Baez, S., Hepatorenal factors in circulatory homeostasis. IV. Tissue origins of the vasotropic principles, VEM and VDM, which appear during evolu- tion of hemorrhagic and tourniquet shock. Circulation, 1951, 3, 42.

33. Shorr, E., and Zweifach, B. W., Hepato-renal factors in circulatory homeostasis. XIX. VEM and VDM mechanisms in nutritional cirrhosis in rats. Federation Proc., 1948, 7, 115.

34. Ellis, L. B., Electrocardiographic abnormalities in severe malnutrition. Brit. Heart J., 1946, 8, 53.

35. Hegglin, R., L'insuffisance cardiaque énergéto-dynamique. Cardiologia, 1949, 15, 65.

36. Oppenheim, M., Die Myokardose bei Lebercirrhose. Schweiz. med. Wchnschr., 1950, 80, 795. 